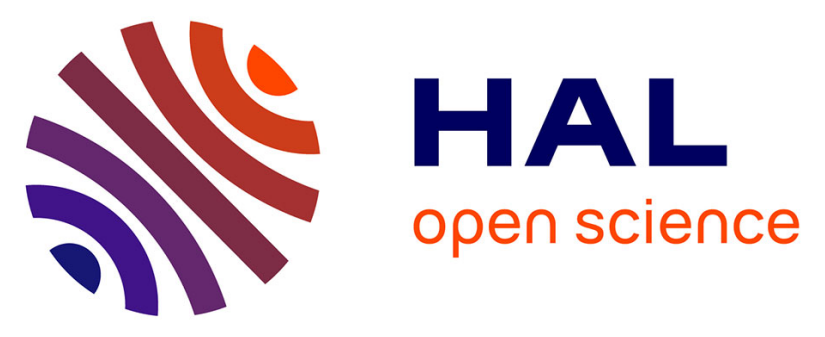

\title{
HLA class II-restricted recognition of common tumor epitopes on human melanoma cells by CD4+ melanoma-infiltrating lymphocytes
}

Eric Le Dréan, Nadine Gervois, Elisabeth Diez, Gilbert Semana, Brigitte Dreno, Francine Jotereau

\section{To cite this version:}

Eric Le Dréan, Nadine Gervois, Elisabeth Diez, Gilbert Semana, Brigitte Dreno, et al.. HLA class II-restricted recognition of common tumor epitopes on human melanoma cells by CD4+ melanoma-infiltrating lymphocytes. European Journal of Immunology, 1995, 25 (10), pp.2732-2736. 10.1002/eji.1830251003 . inserm-03350939

\section{HAL Id: inserm-03350939 https://www.hal.inserm.fr/inserm-03350939}

Submitted on 21 Sep 2021

HAL is a multi-disciplinary open access archive for the deposit and dissemination of scientific research documents, whether they are published or not. The documents may come from teaching and research institutions in France or abroad, or from public or private research centers.
L'archive ouverte pluridisciplinaire HAL, est destinée au dépôt et à la diffusion de documents scientifiques de niveau recherche, publiés ou non, émanant des établissements d'enseignement et de recherche français ou étrangers, des laboratoires publics ou privés. 
Content

highlights from

EULAR now available

\section{Using imaging to optimize patient care in psoriatic arthritis}

Catch up on Janssen's sponsored satellite symposium from this year's EULAR European Congress of Rheumatology, "To see is to believe? Guidance on using imaging to optimize patient care in psoriatic arthritis".

Access a curated collection of content, such as reports, infographics and more to help you apply optimal imaging techniques suitable for psoriatic arthritis diagnosis in clinical practice. Now available online.

\section{Access it all here}




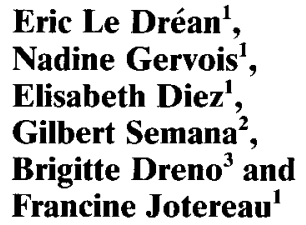

${ }^{1}$ Unité INSERM 211 and Faculté des Sciences de Nantes, Nantes, France

${ }^{2}$ Centre de Transfusion Sanguine de Rennes, Rennes, France

${ }^{3}$ Laboratoire de Dermatologie du CHR de Nantes, Nantes, France

\section{HLA class II-restricted recognition of common tumor epitopes on human melanoma cells by $\mathrm{CD4}^{+}$melanoma-infiltrating lymphocytes}

\begin{abstract}
$\mathrm{CD}^{+} \mathrm{T}$ cell clones derived from lymphocytes infiltrating four human melanomas specifically recognized melanoma-derived tumor epitopes as shown by secretion of tumor necrosis factor (TNF) in vitro upon interaction with autologous melanoma cells, whereas they did not recognize HLA class II-expressing autologous lymphoblasts or HLA class II mismatched allogeneic melanoma cells. Specificity was further established by demonstrating that TNF responses to tumor cells were inhibited by HLA-DR or HLA-DQ monoclonal antibodies. Most of these clones cross-reacted with allogeneic melanoma cells expressing a potentially restricting HLA allele or a structurally similar one. These data show that shared epitopes of human melanoma cells presented on HLA class II molecules are frequently recognized by autologous $\mathrm{CD} 4^{+} \mathrm{T}$ lymphocytes.
\end{abstract}

\section{Introduction}

Although human melanoma tumor-infiltrating lymphocytes (TIL) frequently develop tumor-specific cytotoxic activity in vitro [1-3], it remains unclear whether these cells can also express their cytolytic potential in vivo or whether they remain as precytotoxic precursors whose differentiation is artificially induced in vivo by addition of exogenous IL-2. Cytotoxic T lymphocyte priming, differentiation and function classically depend on lymphokinemediated T helper cell function. Therefore, an important issue concerning the anti-tumor function of melanomaspecific CTL in vivo is to ascertain whether some CD4 ${ }^{+}$ TIL specifically recognize autologous human melanoma cells, which should depend at least on the capacity of these cells to express endogenous melanoma-restricted epitopes in association with HLA class II molecules. Only a few studies have reported HLA class II-restricted responses of $\mathrm{CD}^{+}{ }^{\mathrm{T}} \mathrm{T}$ lymphocytes to melanoma cell or melanomaderived antigens presented by EBV-transformed B cells [4-7]. To address this issue, we looked for specific recognition of four HLA class II-expressing melanoma lines by autologous $\mathrm{CD} 4^{+}$TIL clones.

The data reported here show that all $\mathrm{CD} 4^{+} \mathrm{TIL}$ clones analyzed exhibited HLA class II-dependent responses to autologous melanoma cells, but not to autologous HLA class II-expressing lymphoblasts. This suggests that recruitment of melanoma-reactive $\mathrm{CD} 4^{+} \mathrm{T}$ lymphocytes within HLA class II-expressing metastatic melanomas is a fre-

[I 13461]

Correspondence: Francine Totereau, INSERM U211, Faculté des Sciences, 9 Quai Moncousu, F-44035 Nantes Cedex, France

Abbreviation: TIL: Tumor-infiltrating lymphocytes CaI: Calcium ionophore

Key words: Human melanoma tumor antigen $/ \mathrm{CD}^{+}$tumorinfiltrating lymphocyte / T cell clone / HLA class II restriction quent, if not systematic event, although it has rarely been considered in the literature. This study also established that some of the antigens recognized by these CD4 ${ }^{+}$TIL are commonly expressed by allogeneic melanoma cells.

\section{Materials and methods}

\subsection{Cell lines and TIL clones}

Melanoma cell lines $\mathbf{M}$ were established from metastatic tumor fragments obtained from different patients and cultured in RPMI 1640 containing $10 \%$ FCS. Other melanoma lines used were DEFR, GERL, MZ2 and MAMO (gift from T. Boon, Ludwig Institute for Cancer Research, Brussels, Belgium); DAU, Mel 4 (gift from J. F. Doré, INSERM U218, Lyon, France); and IPC200/B6, IPC205/ 14 and IPC277/5 (gift from C. Aubert, INSERM U119, Marseille, France). EBV-transformed B cell lines were cultured in RPMI 1640 containing $8 \%$ human $\mathrm{AB}$ serum (CTS, Nantes, France). The B17 cell line was established from PBL of patient M17 according to a classical protocol [3]. BH was a DRB $1 * 07$ cell line from the panel of the New York HLA workshop (1987). Normal autologous stimulator cells were T lymphoblasts obtained by stimulating autologous CD $8^{+}$TIL clones with PHA-P (Difco, Detroit, MI) $(1: 1000)$ for 3 days. The allogeneic EBVtransformed B cell line LAZ 388 used for TIL cloning was a gift from T. Hercend. Mouse fibrosarcoma WEHI 164 clone 13 used for TNF production was obtained from T. Boon. TIL were obtained from four different patients by culturing metastatic melanoma fragments in RPMI 1640 containing $150 \mathrm{U} / \mathrm{ml}$ of recombinant IL-2 (gift from Roussel Uclaff, Romainville, France) and antibiotics. Cloning was done by limiting-dilution culture as described [8]. Briefly, different numbers of TIL were seeded in microplates with irradiated feeder and stimulator cells $\left(2 \times 10^{4}\right.$ LAZ cells and $1.5 \times 10^{3}$ autologous melanoma cells) in $200 \mu \mathrm{l}$ rIL-2 medium containing PHA-P (1:1000). Microcultures showing greater than $80 \%$ probability of monoclonality according to the single-hit Poisson law were transferred into new plates with freshly irradiated feeder and stimulator cells. $\mathrm{CD}^{+}$clones were expanded by a similar transfer of $5 \times 10^{3}$ lymphocytes/well every 3-4 weeks. 
Table 1. TNF production (pg/ml) by melanoma-reactive CD4 ${ }^{+}$TIL clones ${ }^{\text {a) }}$

\begin{tabular}{|c|c|c|c|c|c|c|c|c|c|}
\hline \multirow[t]{2}{*}{ Stimulation } & \multicolumn{9}{|c|}{$\mathrm{CD} 4^{+}$clones } \\
\hline & M6-T & M17-137 & M17-311 & M74-6 & M74-33 & M74-94 & M77-180 & M77-181 & M77-184 \\
\hline Medium & 0 & 12 & 44 & 8 & 6 & 8 & 5 & 0 & 1 \\
\hline PMA/CaI & 356 & 1533 & 1700 & 515 & 182 & 185 & 956 & 101 & 119 \\
\hline Autologous melanoma & 33 & 1020 & 1400 & 219 & 27 & 19 & 1091 & 358 & 66 \\
\hline Allogeneic melanoma ${ }^{\text {b) }}$ & 0 & 15 & 31 & 6 & 6 & 5 & 1 & 0 & 0 \\
\hline Autologous blasts ${ }^{(\mathrm{c})}$ & 0 & 5 & 35 & 0 & 5 & 8 & 1 & 0 & 0 \\
\hline EBV-BH transformed B cells ${ }^{\mathrm{c})}$ & ND & ND & ND & ND & ND & ND & 0 & 0 & 0 \\
\hline $\begin{array}{l}\text { EBV-B17 transformed B } \\
\text { cells }{ }^{\text {c) }}\end{array}$ & ND & 91 & 273 & ND & ND & ND & 0 & 0 & 0 \\
\hline
\end{tabular}

a) TNF was determined in the supernatant of clones $\left(2.5 .10^{3} /\right.$ well $)$ stimulated either by melanoma cells $\left(2 \times 10^{4} /\right.$ well $)$ or by a combination of PMA-Cal as a polyclonal activator, as described in Sect. 2.3, using the biological assay on the TNF-sensitive Wehi cell line. Values are from one representative experiment out of three or more.

b) Allogeneic melanoma cells used here did not share a common HLA allele with the donor.

c) Since these cells produced TNF alone, we subtracted this baseline production.

\section{$2.2 \mathrm{mAb}$ and cell staining}

Mouse mAb were: IOT4 (anti-CD4) and anti- $\alpha / \beta \mathrm{T}$ cell receptor from Immunotech (Marseille, France); W6/32 (anti-HLA class I) from ATCC; 206 (anti-HLA class II), B7-21 (anti-HLA DP) and D1-12 (anti-HLA DR), a gift from D. Charron (Institut des Cordeliers, Paris, France); and IOT2d (anti-HLA DQ) from Immunotech. All antiHLA antibodies except IOT2d were used as diluted and filtered ascites fluids. Others were purified antibodies. Cells were labeled by indirect immunofluorescence. Briefly, cells were treated at $4^{\circ} \mathrm{C}$ for 30 min with mouse or rat $\mathrm{mAb}$, washed in PBS and incubated with $\mathrm{F}\left(\mathrm{ab}^{\prime}\right)_{2}$ fragments of goat anti-mouse or anti-rat immunoglobulin for $30 \mathrm{~min}$. Cells were analyzed on a FACScan (Becton Dickinson, Grenoble, France). Background fluorescence was estimated using isotype-matched irrelevant antibodies.

\subsection{TNF detection assay}

At least 10 days after the last stimulation, $\mathrm{T}$ cell clones were washed three times to remove IL-2 and conditioned medium and then stimulated in triplicate cultures either by melanoma cells or autologous lymphoblasts or by a combination of phorbol 12-myristate 13-acetate (PMA) and 4bromo-calcium ionophore A23187 (CaI) (Sigma, I'Isle d' Abeau, Chesne, France) using $10 \mathrm{ng} / \mathrm{ml}$ and $4 \mu \mathrm{M}$, respectively. The T cell/stimulator cell ratio was $2.5 \times 10^{3} / 2 \times 10^{4}$ (up to $10^{5}$ stimulating autologous lymphoblasts were also used) in $100 \mu \mathrm{l}$ medium. After $20 \mathrm{~h}$ of incubation, supernatants were harvested and stored at $-20^{\circ} \mathrm{C}$. Controls were supernatants of $\mathrm{T}$ cells and stimulating cells cultured with medium alone. TNF determination was done by a biological assay based on measurement of WEHI 164 clone 13 cell lysis by clone supernatants, in comparison with a standard curve obtained with rTNF- $\beta$ (Genzyme), as described [9].

\subsection{Inhibition of cytokine secretion with $\mathrm{mAb}$}

Target cells or TIL clones were pretreated with anti-MHC class I and II antibodies and anti-human TcR $\alpha \beta$, respectively. Cells were incubated with serial dilutions of the $\mathrm{mAb}$ in $50 \mu \mathrm{l}$ for $1 \mathrm{~h}$ at $37^{\circ} \mathrm{C}$ before TIL and tumor cells were mixed for TNF production, as described above.

\subsection{HLA class II typing}

HLA class II polymorphism of DR, DP and DQ tumor cell loci was studied by reverse dot-blot hybridization [10] (Innolipa tests, Innogenetics, Belgium). Briefly, tumor DNA samples were amplified using DRB1, DRB3, DRB4 and DRB5 primer mix and a pair of DQB1 and DPB1 primers. The second exon was specifically amplified, and biotinylated nucleotides were incorporated into the amplified DNA during PCR. PCR product was then hybridized with specific oligonucleotide probes immobilized for 30 min as parallel lines on membrane-based strips. After washing, alkaline phosphatase-labeled streptavidin was added. Incubation with BCIP/NBT (bromochloroindolyl phosphate and nitroblue tetrazolium in dimethyl formamide) chromogen resulted in a visually interpretable precipitate. Positive probe numbers were collected using a transparent reading chart, and interpretation was performed by reference to an HLA typing list or with a genotyping program. Cell surface expression of HLA-DR, -DQ and -DP was assessed by indirect immunofluorescence using appropriate $\mathrm{mAb}$ or performed by the CRTS HLA Laboratory (Dr. Bignon, CTS, Nantes, France) using a standard microcytotoxicity procedure.

\section{Results}

\subsection{HLA class II-restricted TNF production by $\mathrm{CD4}^{+}$TIL clones in response to autologous melanoma cells}

We show here that all $\mathrm{CD}^{+}$TIL clones tested were induced to secrete TNF by autologous melanoma cells, but not by autologous lymphoblasts expressing a good level of HLA class II antigens (data not shown) or by fully mismatched allogeneic melanoma cells (Table 1). Since fetal calf serum had been used to culture tumor cells, whereas lymphocytes were cultured with human serum, it was possible that responses to melanoma cells were directed to a calf serum-derived peptide. This possibility was ruled out by the fact that tumor cells established in culture with human serum induced TNF production by the clones (data not shown). Data in Table 2 suggest that TNF production was restricted by HLA class II since it was significantly inhibited, according to clone, by treatment of tumor cells with anti-HLA-DR or anti-HLA-DQ mAb, neither of 
Table 2. HLA class II restriction of TIL clones: inhibition of TNF production ${ }^{\text {a) }}$

\begin{tabular}{lcrrrrrrr}
\hline Monoclonal antibodies & $\begin{array}{c}\text { CD8 } \\
\text { M6-E }\end{array}$ & M6- & M17-137 & M17-311 & M74-94 & M77-180 & M77-181 & M77-184 \\
\hline none & $\mathbf{1 1 1 2}$ & 106 & 1445 & 86 & 12 & 224 & 335 & 1515 \\
anti-HLA-DR & $\mathbf{9 4 8}$ & 107 & $\mathbf{8 0 0}$ & $\mathbf{2 2}$ & 14 & $\mathbf{8 4}$ & $\mathbf{3 8}$ & $\mathbf{2 0}$ \\
anti-HLA-DQ & $\mathbf{1 7 4 5}$ & $\mathbf{4 3}$ & 1552 & 41 & $\mathbf{7}$ & 486 & 350 & 1500 \\
anti-HLA-DP & $\mathbf{1 1 2 4}$ & 109 & 1515 & 91 & 11 & 297 & 592 & 1520 \\
anti-HLA class I & $\mathbf{6 9}$ & 78 & 1515 & 86 & 13 & 291 & 566 & 1500 \\
\hline
\end{tabular}

a) TNF was determined in the supernatant of clones $\left(2.5 \times 10^{3}\right.$ lymphocytes/well $)$ stimulated by autologous melanoma cells $\left(2 \times 10^{4} /\right.$ well) previously incubated or not with anti-HLA mAb. Values are from one representative experiment out of three at $\mathrm{mAb}$ dilution $1: 200$.

Table 3. Cross-reactivity of $\mathrm{CD}^{+}{ }^{+}$TIL clones with autologous and allogeneic melanoma lines, identified on the basis of TNF production $^{\text {a) }}$

\begin{tabular}{|c|c|c|c|c|c|c|c|c|c|c|}
\hline \multirow{2}{*}{$\begin{array}{l}\text { Stimulating } \\
\text { melanoma } \\
\text { lines }\end{array}$} & \multicolumn{10}{|c|}{$\mathrm{CD}^{+}$clones } \\
\hline & M6-T & M17-137 & M17-311 & M74-6 & M74-94 & M77.59 & $M 77-152$ & M77-180 & M77-181 & M77-184 \\
\hline M6 & ++ & - & + & - & - & - & - & - & - & + \\
\hline M17 & - & ++ & ++ & + & + & & & - & - & ++ \\
\hline M74 & - & - & - & + & + & - & - & - & - & - \\
\hline M77 & - & - & + & - & - & + & ++ & $t+t$ & $+t+$ & $+t$ \\
\hline M47 & & & & - & + & & & & & \\
\hline M60 & - & - & - & - & - & & & ++ & + & - \\
\hline M67 & - & + & - & ++ & + & -- & ++ & - & - & - \\
\hline GERL & - & - & ++ & + & + & - & - & - & - & - \\
\hline MZ2-MEL2-2 & - & - & +++ & + & ++ & - & - & - & - & - \\
\hline MAMO & - & & ++ & - & - & & & - & - & - \\
\hline IPC-277/5 & - & & - & + & + & & & - & - & - \\
\hline IPC-205/14 & - & & - & & & ++ & - & - & +++ & - \\
\hline IPC-200B/6 & - & + & - & & & - & ++ & +++ & +++ & - \\
\hline DAUDEL & - & & & - & & - & ++ & $t+t$ & - & - \\
\hline MEL-4 & - & & & & & & & +++ & - & - \\
\hline
\end{tabular}

a) TNF production was determined as in Table 1 . TNF productions are indicated by: $(-)=$ no production, $(+)=10$ to $100 \mathrm{pg} / \mathrm{ml},(++)$ $=100$ to $500 \mathrm{pg} / \mathrm{ml},(+++)=>500 \mathrm{pg} / \mathrm{ml}$. These productions were determined as the mean of three independent experiments.

which inhibited TNF production by a $\mathrm{CD}^{+}$clone. Moreover, data in Table 1 show that M77 clones did not recognize EBV-transformed B cells B17 and BH, which share all the potentially restricting $\mathrm{DR}$ alleles for these clones, whereas M17 clones recognized the autologous EBV-transformed B cell line. EBV-transformed B cell recognition could not be tested for M6 and M74 clones because of a lack of the appropriate cell lines required to check recognition of epitopes on all potentially restricting HLA molecules.

\subsection{Stimulation of TNF production by allogeneic melanoma cells}

As shown in Table 3 , all $\mathrm{CD} 4^{+}$clones, with the exception of the HLA-DQ-restricted clone M6-T, were stimulated to produce TNF not only by autologous melanoma cells but also by a few allogeneic melanoma lines, most of which shared at least one of the restricting isotype alleles expressed by autologous cells. In some cases, higher amounts of TNF were induced by allogeneic than by autologous melanoma cells.

\subsection{Cross-reactivity of CD4 ${ }^{+}$TIL clones suggests that their restriction pattern may be monogamous or promiscuous}

As the restricting HLA isotype of the clones was shown by inhibition experiments, we tried to identify fine HLA restriction by determining the HLA phenotype of allogeneic melanoma cells recognized by these clones. Table 4 shows the alleles found at the DNA level in autologous and allogeneic cell lines recognized by HLA-DR-restricted clones. Expression at the surface of these cells of HLADRB1, -DRB3, -DRB4 and DRB5 cells was further checked by immunofluorescence or microcytotoxicity. These data showed that two DR alleles, DRB1*07 and DRB $4 * 0101$, were shared by all cell lines recognized by clones M77-180. All cell lines recognized by clone M77-181 shared DRB $4 * 0101$. In addition, either DRB1*1601 or the structurally similar DRB1*1501 allele was present in all cell lines recognized by clones M17-137, M77-181 and M77184. These alleles thus represent two potential restricting elements for clones M17-137 and M77-184 as well as for clone M77-181. 
Table 4. DR subtypes of melanoma lines inducing TNF production by DR-restricted clones ${ }^{\text {a) }}$

\begin{tabular}{|c|c|c|c|c|c|c|}
\hline Clones & $\begin{array}{l}\text { Tumor cell lines } \\
\text { recognized }\end{array}$ & DRB1 & DRB1 & DRB3 & DRB4 & DRB5 \\
\hline M17-137 & $\begin{array}{c}\text { M17 } \\
\text { M67 } \\
\text { IPC200B/6 } \\
\text { M6 }\end{array}$ & $\begin{array}{r}0801 \\
13 \\
07 \\
0101\end{array}$ & $\begin{array}{r}1601 \\
15 \\
15 \\
15\end{array}$ & $\begin{array}{c}- \\
\mathrm{ND} \\
- \\
-\end{array}$ & $\begin{array}{c}- \\
- \\
0101 \\
-\end{array}$ & $\begin{array}{c}02 \\
\text { ND } \\
0101 \\
\text { ND }\end{array}$ \\
\hline M17-311 & $\begin{array}{c}\text { M17 } \\
\text { M77 } \\
\text { GERL } \\
\text { MZ2 } \\
\text { MAMO }\end{array}$ & $\begin{array}{r}0801 \\
07 \\
0101 \\
0101 \\
11\end{array}$ & $\begin{array}{r}1601 \\
1601 \\
1302 \\
0101 \\
11\end{array}$ & $\begin{array}{c}- \\
- \\
0101 \\
- \\
-\end{array}$ & $\begin{array}{c}- \\
0101 \\
- \\
- \\
-\end{array}$ & $\begin{array}{l}02 \\
02 \\
- \\
- \\
-\end{array}$ \\
\hline M77-180 & $\begin{array}{l}\text { M77 } \\
\text { M60 } \\
\text { IPC200B/6 } \\
\text { DAUDEL } \\
\text { MEL4 }\end{array}$ & $\begin{array}{l}07 \\
07 \\
07 \\
07 \\
07\end{array}$ & $\begin{array}{r}1601 \\
1601 \\
15 \\
11 \\
04\end{array}$ & $\begin{array}{c}- \\
- \\
- \\
0202 \\
-\end{array}$ & $\begin{array}{l}0101 \\
0101 \\
0101 \\
0101 \\
0101\end{array}$ & $\begin{array}{r}02 \\
02 \\
0101 \\
- \\
-\end{array}$ \\
\hline M77-181 & $\begin{array}{c}\text { M77 } \\
\text { M60 } \\
\text { IPC205/14 } \\
\text { IPC200B/6 }\end{array}$ & $\begin{array}{r}07 \\
07 \\
0404 \\
07\end{array}$ & $\begin{array}{r}1601 \\
1601 \\
15 \\
15\end{array}$ & $\begin{array}{l}- \\
- \\
- \\
-\end{array}$ & $\begin{array}{l}0101 \\
0101 \\
0101 \\
0101\end{array}$ & $\begin{array}{r}02 \\
02 \\
0101 \\
0101\end{array}$ \\
\hline M77-184 & $\begin{array}{c}\text { M6 } \\
\text { M17 } \\
\text { M77 }\end{array}$ & $\begin{array}{r}0101 \\
0801 \\
07\end{array}$ & $\begin{array}{r}15 \\
1601 \\
1601\end{array}$ & $\begin{array}{l}- \\
- \\
-\end{array}$ & $\begin{array}{c}- \\
\overline{0101}\end{array}$ & $\begin{array}{r}\text { ND } \\
02 \\
02\end{array}$ \\
\hline
\end{tabular}

a) HLA class II typing was done by reverse dot-blot hybridization after second exon amplification by PCR, as described in Sect. 2.5 .

\section{Discussion}

This study shows that CD4 ${ }^{+}$TIL clones from four human melanoma tumors exhibited an HLA class II-restricted TNF response to melanoma cells, but not to autologous T lymphoblasts. Possible recognition of serum determinants, already described for $\mathrm{CD}^{+}$clones in culture, was ruled out. Since the expression of the HLA class II-restricting isotype by $\mathrm{T}$ lymphoblasts was determined for each assay and shown to be generally similar to that expressed by autologous tumor cells, our data suggest that CD4 ${ }^{+}$TIL clones recognize tumor-restricted antigens. Additional data obtained using EBV-transformed B cell lines show that some, but not all, melanoma antigens recognized by $\mathrm{CD}^{+}$clones were shared by EBV-transformed B cells.

We also established that the epitopes recognized by DRrestricted TIL were shared by several melanoma lines. In contrast, one DQ-restricted clone, M6-T, did not crossreact with any melanome line sharing one of the two potentially restricting $D Q$ elements. This may have been due to recognition by this clone of a rare or mutated antigen, or to the presentation of a common melanoma antigen by a rare $D Q$ molecule expressed on M6 tumor cells, such as the DQB $1 * 0504$ allele found at the DNA level in this cell line (data not shown), which is expressed in only 4 out of 26 ethnic groups analyzed and at very low frequencies [11], or a hybrid molecule either inter- (DQ/DR) or intra-isotypic $[12,13]$.

Data from HLA typing of melanoma lines suggest that the antigen-presenting allele to clone M77-180 was either DRB $1 * 07$ or DRB $4 * 0101$. Since all the cells recognized by clones M17-137 and M77-184 expressed one of the two very structurally similar alleles DRB $1 * 1601$ or $* 1501$, it is possible that these clones recognized the antigen on these two alleles indifferently. The same conclusion holds true for clone M77-181. However, the DRB4*0101 allele shared by all melanoma lines which this clone recognized was also a potentially restricting allele. Promiscuous antigen binding to several HLA-DR alleles has already been reported [14]. Our recent demonstration that M17-311 is in fact a mixture of two $\mathrm{CD}^{+}$clones (Pannetier et al., unpublished), probably accounts for the cross-reactions of this clone with melanoma lines of quite distinct DR phenotypes.

Since all the $\mathrm{CD} 4^{+}$clones analyzed here reacted against the autologous tumor, it appears that the development or recruitment of melanoma-reactive $\mathrm{CD}^{+}$lymphocytes within human metastatic melanomas is a frequent event, although probably limited to HLA class II-expressing tumors. This argues for a common presentation of endogenous melanoma epitopes on HLA class II molecules and an effective recognition of these complexes by autologous $\mathrm{CD}^{+}$T lymphocytes. However, it is noteworthy that most $\mathrm{CD}^{+}{ }^{+}$clones used here produced TNF, but no detectable IL-2 in response to antigen presentation by melanoma cells in vitro, despite the production of significant amounts of IL-2 in response to stimulation by anti-CD3 or PMA-CaI [15]. If a similar limitation of $\mathrm{CD}^{+}$TIL responses to melanoma antigens also exists in vivo, the ability of these cells to exert a significant function is questionable. Limited responses of TIL could result from anergy induction or other improper $\mathrm{T}$ cell triggering related to $\mathrm{HLA}$ or antigen density, or to antigen conformation.

Taken together, our data confirm and extend previous reports about melanoma antigen recognition by $\mathrm{CD} 4^{+} \mathrm{T}$ cells [4-7]. In one of these studies [7] it was established 
that a product of the tyrosinase gene is recognized by $\mathrm{CD}^{+}$TIL on EBV-transformed B cells pulsed with melanoma cell extracts. In the other two studies, as in the present one, the nature of the target antigens was not indicated. Epitopes recognized by our DR- or DQ-restricted clones may belong to one of two types of shared melanoma antigens recognized by cytotoxic $\mathrm{CD} 8^{+}$lymphocytes: either melanocytic differentiation antigens or genes, such as MAGE 1, of unknown function but restrictively expressed by tumor tissues (see [16] for a review). The antigens recognized by M17 clones and expressed by EBVtransformed B cells would either belong to the latter type or be classified as autologous antigens not expressed or not efficiently processed by HLA class II-expressing T lymphoblasts. On the other hand, $\mathrm{CD}^{+}$clones lacking crossreactivity with allogeneic melanoma lines may recognize mutated protein products.

The recent identification of peptide recognized by $\mathrm{CD} 8^{+}$ lymphocytes on melanoma cells has encouraged cancer therapists to devise methods to exploit these peptides as vaccines to induce cytotoxic $T$ cell responses [16]. However, animal models have shown that $T$ helper cells are often crucial agents of tumor rejection, either through induction of CTL-mediated activities or as direct effectors by lymphokine production [17]. If some of the epitopes recognized on melanoma cells by $\mathrm{CD} 4^{+} \mathrm{T}$ lymphocytes are expressed restrictively on tumor cells, they will represent new targets against which to induce or stimulate antitumor responses. This indicates the need to identify HLA class II-restricted tumor epitopes, whose existence is suggested here, to facilitate the development of alternative vaccination therapies involving $T$ helper cells. This could prove more effective than therapies already under way that seek to develop CTL activities.

This work was supported by funds from INSERM, by grant no. 6494 from the "Association pour la Recherche sur le Cancer" and by funds from the Ligue Nationale Contre le Cancer.

Received August 17, 1994; in revised form July 3, 1995; accepted July 24, 1995.

\section{References}

1 Itoh, K., Platsoucas, C. D. and Balch, M. C., J. Exp. Med. 1988. 168: 1419

2 Topalian, S. L., Solomon, D. and Rosenberg, S. A., J. Immunol. 1989. 142: 3714.

3 Pandolfino, M. C., Viret, C., Gervois, N., Guilloux, Y., Davodeau, F., Diez, E. and Jotereau, F., Eur. J. Immunol. 1992. 22: 1795 .

4 Chen, Q. and Hersey, P., Int. J. Cancer 1992. 51: 218.

5 Kharkevitch, D., Seito, D., Balch, G., Maeda, T., Balch, C. and Itoh, K., Int. J. Cancer 1994. 58: 317.

6 Takahashi, T., Chapman, P., Young Yang, S., Hara, S., Vijayasaradhi, S. and Houghton, A., J. Immunol. 1995. 154: 772.

7 Topalian, S., Rivoltini, L., Mancini, M., Markus, N., Robbins, P., Kawakami, Y. and Rosenberg, S., Proc. Natl. Acad. Sci. USA 1994. 91: 9461.

8 Gervois, N., Heuze, F., Diez, E. and Jotereau, F., Eur. J. Immunol. 1990. 20: 825.

9 Traversari, C., van der Bruggen, P., van den Eynde, B., Hainaut, P., Lemoine, C., Ohta, N., Old, L. and Boon, T., Immunogenetics 1992. 35: 145.

10 Buyse, I., Dacorter, P., Baens, M., Cuppens, H., Semana, G., Edmonds, M. P., Marynen, P. and Cassiman, J. J., Tissue Antigens 1993. 41: 1.

11 Tadshi, I., Tatsuya, A., Akwiori, K., Katsushi, T. and Takashi, $\mathrm{G}$, in Tsuji, K., Aizawa, M. and Sasazukai, T. (Eds.), HLA 91. Proceeding of the eleventh International Histocompatibility Workshop and Conference. Vol. 1. Oxford University Press, New York 1992, p. 1065.

12 Charron, D. J., Lotteau, V. and Turmel, P., Nature 1984. 312. 157.

13 Lotteau, V., Teytar, L., Bourroughs, D. and Charron, D. J., Nature 1987. 329: 339.

14 Chicz, R., Urban, R., Gorga, J., Vignali, D., Lane, W. and Strominger, J., J. Exp. Med. 1993. 178: 27.

15 Guilloux, Y., Viret, C., Gervois, N., Le Dréan, E., Pandolfino, M. C., Diez, E. and Jotereau, F., Eur. J. Immunol. 1994. 24: 1966.

16 Pardoll, D. M., Nature 1995. 369: 357.

17 Nagarkatti, M., Clary, S. and Nagarkatti, P. S., J. Immunol. 1990. 144: 4898 . 